\title{
Erratum to: Suberoylanilide hydroxamic acid, an inhibitor of histone deacetylase, suppresses vasculogenic mimicry and proliferation of highly aggressive pancreatic cancer PaTu8988 cells
}

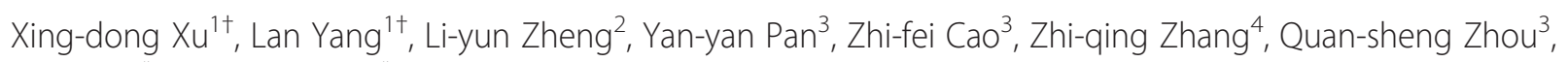
Bo Yang ${ }^{1^{*}}$ and Cong Cao ${ }^{4^{*}}$

\section{Erratum}

Unfortunately, the original version of this article [1] contained an error within Fig. 5. For testing Sema4D protein expression in PaTu8988 cells with/out SAHA treatment, the protein samples of Fig. 2D were re-tested by Western blot assay using Sema4D antibody (Fig. 5E). The correct version of Fig. 5E can be found below. This does not alter the conclusion of the result.

\section{Sema4D \\ Tubulin

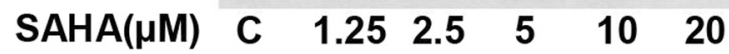

Fig. 5 PaTu8988 cells were incubated with SAHA at indicated dosage for 48 hours, the protein expressions of Sema4D and tubulin were tested by Western blots. Experiments in this figure were repeated three times, and similar results were obtained. e SAHA suppresses PaTu8988 cell vasculogenic mimicry (VM)

\footnotetext{
*Correspondence: dryangbosz@163.com; caocong@suda.edu.cn ${ }^{\dagger}$ Equal contributors

'Department of General Surgery, the Third Hospital affiliated to Soochow University, Changzhou City, Jiangsu 213003, China

${ }_{4}^{4}$ Jiangsu Key Laboratory of Translational Research and Therapy for Neuro-Psycho-Diseases and Institute of Neuroscience, Soochow University, Suzhou, Jiangsu 215021, China

Full list of author information is available at the end of the article
}

\begin{abstract}
Author details
'Department of General Surgery, the Third Hospital affiliated to Soochow University, Changzhou City, Jiangsu 213003, China. ${ }^{2}$ Department of Neurology, the First Affiliated Hospital of Soochow University, Suzhou, China. ${ }^{3}$ Cyrus Tang Hematology Center, Soochow University, Suzhou, Jiangsu 215123, China. ${ }^{4}$ Jiangsu Key Laboratory of Translational Research and Therapy for Neuro-Psycho-Diseases and Institute of Neuroscience, Soochow University, Suzhou, Jiangsu 215021, China.
\end{abstract}

Received: 8 June 2016 Accepted: 8 June 2016 Published online: 04 July 2016

\section{References \\ 1. Xu X, Yang L, Zheng L, Pan Y, Cao Z, Zhang Z, Zhou Q, et al. Suberoylanilide hydroxamic acid, an inhibitor of histone deacetylase, suppresses vasculogenic mimicry and proliferation of highly aggressive pancreatic cancer PaTu8988 cells. BMC Cancer. 2014;14:373. doi:10.1186/1471-2407-14-373.}

Submit your next manuscript to BioMed Central and we will help you at every step:

- We accept pre-submission inquiries

- Our selector tool helps you to find the most relevant journal

- We provide round the clock customer support

- Convenient online submission

- Thorough peer review

- Inclusion in PubMed and all major indexing services

- Maximum visibility for your research

Submit your manuscript at www.biomedcentral.com/submit (c) 2016 The Author(s). Open Access This article is distributed under the terms of the Creative Commons Attribution 4.0 International License (http://creativecommons.org/licenses/by/4.0/), which permits unrestricted use, distribution, and reproduction in any medium, provided you give appropriate credit to the original author(s) and the source, provide a link to the Creative Commons license, and indicate if changes were made. The Creative Commons Public Domain Dedication waiver (http://creativecommons.org/publicdomain/zero/1.0/) applies to the data made available in this article, unless otherwise stated. 